\title{
Congenital Cytomegalovirus Infection - Lessons from a Clinical Case
}

\author{
Zhivka Stoykova $^{1,2}$, Liliya Ivanova ${ }^{1,2}$, Snejinka Cvetkova $^{3}$, Diana Yordanova ${ }^{3}$ \\ ${ }^{1}$ Laboratory of Virology, St Marina University Hospital, Varna, Bulgaria \\ ${ }^{2}$ Department of Microbiology and Virology, Medical University of Varna, Bulgaria \\ ${ }^{3}$ Department of Obstetrics and Gynecology, Medical University of Varna, Bulgaria
}

Corresponding author: Zhivka Stoykova, Department of Microbiology and Virology, Medical University of Varna, 55 Marin Drinov St. 9002, Varna, Bulgaria; E-mail: jivita77@abv.bg.

Received: 24 Apr 2019 Accepted: 2 Aug 2019 Published: 30 June 2020

Citation: Stoykova Zh, Ivanova L, Cvetkova S, Yordanova D. Congenital cytomegalovirus infection - lessons from a clinical case. Folia Med (Plovdiv) 2020;62(2):403-7. doi: 10.3897/folmed.62.e49840.

\section{Abstract}

Background: Cytomegalovirus (CMV) is a worldwide spread herpes virus that establishes a latent infection after the primary infection. It becomes a major problem in immunocompromised patients and in cases of primary or reactivated infection during pregnancy. CMV is the most common congenital infection and is the leading infectious cause of sensoneural deafness and cerebral mental retardation.

Aim: To raise the attention to the discordance in our knowledge of cCMV infection and the implementation of the knowledge in practice.

Materials and methods: CMV-DNA was extracted from saliva and plasma samples according to the protocol of DNA-Sorb-A, Sacace, Biotechnologies, Italy. Polymerase chain reaction (PCR) was performed using a commercial kit based on the Taq-man principle: Quantitative RT-PCR for CMV-DNA detection (Sacace, Biotechnologies, Italy). The linear range of the CMV Real-TM Quant PCR test is $500-1000000$ copies $/ \mathrm{ml}$, and the reported sensitivity is 400 copies $/ \mathrm{ml}$.

Results: The infant was born with clinical manifestations involving development of hepatosplenomegaly, chorioretinitis, anemia, microcephaly and simultaneous dilatation of the brain ventricles. CMV infection was confirmed using modern PCR studies.

Conclusions: This case highlights the need for specific virological/PCR tests to be performed for all children with the least suspected congenital infection, especially when there is an option of a specific treatment.

\section{Keywords}

cCMV, CMV-DNA detection, saliva, screening

\begin{tabular}{llll}
\multicolumn{2}{l}{ Abbreviations used in the article } & cCMV: & congenital CMV \\
\hline ALAT: & alanine aminotransferase & ELISA: & enzyme linked immunosorbent assay \\
APV: & artificial pulmonary ventilation & gGTP: & gamma-glutamyl transpeptidase \\
ASAT: & aspartate aminotransferase & PCR: & polymerase chain reaction \\
CMV: & cytomegalovirus & QRT-PCR: & quantitative real time polymerase chain reaction \\
\hline
\end{tabular}

\section{INTRODUCTION}

The cytomegalovirus infection is caused by a large DNA virus of the Herpesviridae family. Once CMV enters the body, it remains there for a lifetime. Generally, healthy adults are asymptomatic and after the primary infection the virus usually stays in a dormant latent phase. ${ }^{1}$ However, the virus may become active again during a time of weakened im- 
munity and poses a considerable risk in pregnancy. ${ }^{2} \mathrm{CMV}$ is the most common congenital viral infection and is the leading infectious cause of sensoneural deafness and cerebral mental retardation. It is estimated that about 40,000 children in USA ( $0.2 \%$ to $2 \%$ of all deliveries) are born with $\mathrm{CMV}$, resulting in about 400 fatal cases each year. ${ }^{3}$ Only 10 to $15 \%$ of children with congenital CMV infection exhibit clinical signs at birth, although even children who appear asymptomatic at birth are at risk for neurodevelopmental sequelae. ${ }^{4}$ Presently, CMV can be encountered in every fourth woman in childbirth age. ${ }^{5}$ The low pathogenicity of the virus in healthy adults is in sharp contrast to its impact on the fetus which can cause life-threatening damage to the newborn infant. The harm for the fetus is even more serious in cases where the mother had a primary infection and has not developed any specific CMV antibodies. Usually, the congenital infection resulting from reactivation of a latent maternal CMV infection is clinically milder. It is important to note that infecting the fetus or the newborn infant can happen only in cases of active mother's virus infection. During pregnancy, the virus often attacks the nervous system of the fetus which is associated with early miscarriages or with the development of a number of defects in the newborn infants, $20-30 \%$ of whom die. ${ }^{6}$ Unfortunately, the congenital cytomegalovirus infection in clinical practice is not susceptible to treatment and therefore preventive measures are warranted. It is advisable that the activity of the virus in pregnant women should be monitored and controlled by screening each trimester ${ }^{7}$, especially after previous unsuccessful pregnancy as it has been in the present case.

\section{AIM}

To raise the awareness of the discordance between our knowledge of cCMV infection and the implementation of the knowledge in practice.

\section{CASE REPORT}

We present a case of a prematurely born male infant with congenital cytomegalovirus infection. The child was born from a third pathological pregnancy of a 30-year-old woman, after previous birth to a healthy child 11 years ago and a previous stillbirth in the eight month of pregnancy (no medical records available). The child was delivered in $30 \mathrm{~g}$. w. with a weight of $1130 \mathrm{~g}$ and a length of $34 \mathrm{~cm}$, Apgar score $1 / 1 / 3$, in an extremely severe general condition, with alabaster pale skin, petechial rash over the body and generalized edema. On clinical examination, the baby was found to have extreme hepatomegaly - liver under the umbilical line and an excessively enlarged spleen. Due to erythroblastosis fetalis (anemic form) an exsanguinotransfusion was done by protocol with an O-Rh (-) erythrocyte mass with AB-plasma. The child was under APV, oxygen therapy, surfactant, wide-spectrum antibiotics due to the high risk of infection after the invasive procedure, anti-edema therapy, plasma transfusion and immunovenin which was administered repeatedly, with complete and complementary parenteral nutrition. In the following days, the child remained in an extremely severe condition with seizures, high APV/ oxygen-dependency, and a low nutritional tolerance. Many brain cysts and cataract appeared also.

On ultrasound examination, there was evidence of cardiomegaly and left ventricular hypertrophy. Transfontanel echography was quite difficult to perform, due to swelling of the soft tissues of the head, but with evidence of brain edema and calcifications bilaterally, hyperechogenic foci in both sides of the ventricular wall and asymmetric ventriculomegaly. The right front lobe was more dilated; the left was difficult to observe due to brain edema. The ophthalmologic examination revealed a hyperplastic glass vitreous body, partial illumination, eye fundus was not visible.

The first laboratory results showed extremely low hemoglobin: $53 \mathrm{~g} / \mathrm{l}$ and platelets: $28 \times 10^{9}$ l, elevated leucocytes: $184 \times 10^{9} \mathrm{l}$, normal CRP- $1.37 \mathrm{mg} / \mathrm{l}$, high blood bilirubin: 126 mmol/l before exsanguinotransfusion, ALAT: 47 u/l, ASAT: $127 \mathrm{u} / \mathrm{l}, \mathrm{gGTP}: 363 \mathrm{u} / \mathrm{l}$ which suggests liver involvement. From microbiology tests of samples: nose and blood culture -without growth, throat - M. morganii, ear - S. haemolyticus, stomach aspirate - S. maltophilia. The serological profile showed anti CMV IgM: $6.8 \mathrm{R}>1.1 \mathrm{R}$, positive; anti-CMV IgG: $100 \mathrm{IU} / \mathrm{ml}>22 \mathrm{IU} / \mathrm{ml}$, positive (ELISA Euroimmun, Germany). The result from a quantitative RT-PCR assay (Quant CMV, Sacace, Biotechnologies, Italy) from plasma sample showed: $45722 \mathrm{IU} / \mathrm{ml}$ (4.66 lg) CMV-DNA. All PCR reactions were performed in the presence of Internal Control (IC) to identify possible inhibition of the reaction and the endogenous IC-glob (b-globine gene) to assess the adequacy of the material and its storage, according to the manufacturer's protocol. Five days later in the plasma test, we collected $150 \mu \mathrm{l}$ saliva and tested it with the same assay. The result showed even higher viral load of 3,725,965 IU/ml (6.57 lg). Specific treatment with cymevene i.v. was started in a dose of $12 \mathrm{mg} / \mathrm{kg}$ per day for 6 weeks with control of the kidney and liver function, which the baby tolerated well and started gaining weight. The child was admitted to an intensive child care unit at day 52 after the delivery with a weight of $2160 \mathrm{~g}$ in order to continue the specific treatment course. Nuclear magnetic resonance findings: evidence of extensive areas of encephalomalacia supratentorial bilateral with reduction of the brain parenchyma, pronounced dilatation of the ventricular system with evidence of massive intraventricular hemorrhage with prescription. At day 90, in control PCR test after the specific treatment was discontinued, we did not detect viral load in his plasma sample, additionally there was decline of anti CMV IgM antibodies to the gray zone: $0.84 R>0.8 R<1.1 R$, and anti-CMV IgG antibody titer reduction to $61 \mathrm{RU} / \mathrm{ml}$. We were able to investigate the child again at 5 months of age when we detected viral reactivation with again positive viral load in plasma (197 IU/ $\mathrm{ml})$ and much higher in saliva (201,518 IU/ml), anti-CMV IgM antibodies were negative but with increase of CMV IgG 
antibodies to $167 \mathrm{RU} / \mathrm{ml}$, which also confirms reactivation (Table 1). cal test was performed relatively late after birth, as clinical attention was directed mainly towards $\mathrm{Rh}$ incompatibility.

We consider that the mother is prone to reactivation of

Table 1. Virology results of the CMV infected infant

\begin{tabular}{lllll}
\hline Age & $\begin{array}{l}\text { Anti CMV IgM } \\
(\mathbf{R})\end{array}$ & $\begin{array}{l}\text { Anti CMV IgG } \\
(\mathbf{R U} / \mathbf{m l})\end{array}$ & $\begin{array}{l}\text { PCR (plasma) } \\
(\mathbf{I U} / \mathbf{m l})\end{array}$ & $\begin{array}{l}\text { PCR (saliva) } \\
(\mathbf{I U} / \mathbf{m l})\end{array}$ \\
\hline 1 month & $(+) 6.8$ & $(+) 100$ & $45722=\lg 4.7$ & $3725965=\lg 6.6$ \\
3 months & $(+/-) 0.84$ & $(+) 61$ & $(-)$ Negative & Not tested \\
5 months & $(-)$ Negative & $(+) 167$ & $197=\lg 2.3$ & $201518=\lg 5.3$ \\
\hline
\end{tabular}

\section{DISCUSSION}

As a herpesvirus, once CMV enters the body, it causes a life-long infection. ${ }^{8}$ Normally, CMV is dormant in the body and causes no damage. The virus becomes active when the immunity is weakened, at time of frequent colds, stress, and pregnancy. It is important to note that infection of the fetus or neonate can take place only in an active mother's viral infection. According to world statistical data, more than $80 \%$ of the population is infected with CMV. The estimated seroprevalence in North-eastern Bulgaria is $78.4 \% .{ }^{9}$ The seroprevalence in 121 pregnant women from the same region is $85.5 \%$ (our unpublished data). Due to the high seroprevalence only the IgG avidity tests and tests by DNA analysis clearly demonstrates recent/active viral infection in the mother and proves reactivation.

The most serious complication caused by active cytomegalovirus infection during pregnancy is an infection of the fetus. In pregnancy, the virus affects the nervous system of the fetus which attributes to early miscarriage or development of a number of defects in neonate, fatal in $20-30 \%$ of cases..$^{10} \mathrm{CMV}$ is the most common congenital viral infection worldwide and is the leading infectious cause of sensoneural deafness and cerebral mental retardation. Depending on the time of primary CMV infection, the frequency of viral transmission to the fetus increases progressively from $30 \%$ around the concept and in the first trimester to $70 \%$ in the third trimester of pregnancy. ${ }^{11,12}$ The estimated risk of vertical transmission in the first trimester of pregnancy is $36-45 \%$, but with the worst outcome. ${ }^{13}$ Only $10 \%$ of the infected newborn babies are symptomatic at birth and $15 \%$ of asymptomatic newborn babies display developmental disorders later in life. ${ }^{14}$ The possibility of CMV transmission to the fetus is estimated to be $30-40 \%$ in primary maternal infection and decreases to $0.5-1.4 \%$ in immune women before the present pregnancy. ${ }^{15}$

We believe that, based on the virology lab data and the severe clinical presentation at birth, the described case herein is a congenital CMV infection that occurred in the early stages of pregnancy. In addition, it is very likely that the same virus reactivation can be responsible for the previous stillbirth in this mother with high avidity anti CMV IgG results in the present case. The first specific virologi-
CMV infection that probably has caused the adverse outcome of the previous pregnancy and the child's multiorgan impairment from the present case. The available serological data only show a maternal CMV chronical infection: high avidity index of the specific IgG. Unfortunately, there is no test to show which immune mothers will transmit the infection to the fetus. The lack of data on the mother's viral load in PCR test during the pregnancy does not allow us to confirm reactivation of mother's chronical CMV infection. Nevertheless, the findings in the infant are strongly suggestive of congenital CMV infection.

\section{CONCLUSION}

Serology and PCR follow-up of pregnant women with pre-existing pregnancies with adverse outcome is strongly recommended. Clinicians always have to pay attention to cCMV infection in cases of newborn with evidence of fetal distress, considering the early onset of antiviral therapy. Although the effects of cCMV are difficult to overcome, management of the CMV infection in the infant is possible through the administration of antiviral drugs to suppress viral propagation and to facilitate the passage of the virus from active phase to latent phase, not to cause more damage. As a conclusion, in case of suspected congenital infection in the newborn, virological/PCR studies are obligatory.

\section{REFERENCES}

1. Gaytant MA, Rours GI, Steegers EA, et al. Congenital cytomegalovirus infection after recurrent infection: case reports and review of the literature. Eur J Pediatr 2003; 162: 248-53.

2. Boppana SB, Rivera LB, Fowler KB, et al. Intrauterine transmission of cytomegalovirus to infants of women with preconceptional immunity. N Engl J Med 2001; 344:1366-71.

3. Cannon MJ, Davis KF. Washing our hands of the congenital cytomegalovirus disease epidemic. BMC Public Health 2005; 5:70.

4. Boppana SB, Fowler KB, Britt WJ, et al. Symptomatic congenital cytomegalovirus infection in infants born to mothers with preexisting immunity to cytomegalovirus. Pediatrics 1999; 104: 55-60. 
5. Kenneson A, Cannon MJ. Review and meta-analysis of the epidemiology of congenital cytomegalovirus (CMV) infection. Rev Med Virol 2007; 17: 253-76.

6. Raynor BD. Cytomegalovirus infection in pregnancy. Semin Perinatol 1993; 17: 394-402.

7. Barbi M, Binda S, Caroppo S, et al. Neonatal screening for congenital cytomegalovirus infection and hearing loss. J Clin Virol 2006; 35: 206-9.

8. Enders G, Bader U, Lindemann L, et al. Prenatal diagnosis of congenital cytomegalovirus infection in 189 pregnancies with known outcome. Prenat Diagn 2001; 21(5): 362-77.

9. Stoykova Zh, Ivanova L, Todorova T, et al. Seroprevalence of cytomegalovirus in the North-Eastern Bulgarian population, 20032015. Acta Microbiologica Bulgarica 2016; 32(3): 27-32.

10. Revello MG, Zavattoni M, Baldanti F, et al. Diagnostic and prognostic value of human cytomegalovirus load and IgM antibody in blood of congenitally infected newborns. J Clin Virol 1999; 14:57-66.

11. Bodeus M, Kabamba-Mukadi B, Zech F, et al. Human cytomegalovirus in utero transmission: follow-up of 524 maternal seroconversions. J Clin Virol 2010; 47: 201-2.

12. Revello MG, Fabbri E, Furione M, et al. Role of prenatal diagnosis and counselling in the management of 735 pregnancies complicated by primary human cytomegalovirus infection: a 20 -year experience. J Clin Virol 2011; 50: 303-7.

13. Enders $G$, Daiminger $A$, Bader $U$, et al. Intrauterine transmission and clinical outcome of 248 pregnancies with primary cytomegalovirus infection in relation to gestational age. J Clin Virol 2011; 52(3): 244-6.

14. Revello MG, Gerna G. Diagnosis and management of human cytomegalovirus infection in the mother, fetus, and newborn infant. Clin Microbiol Rev 2002; 15: 680-715.

15. Schleiss MR. Congenital cytomegalovirus infection: update on management strategies. Curr Treat Option N 2008; 10(3): 186-92. 


\title{
Врождённая цитомегаловирусная инорекция - выводы на примере клинического случая
}

\author{
Живка Стойкова ${ }^{1,2}$, Лилия Иванова ${ }^{1,2}$, Снежинка Цветкова ${ }^{3}$, Диана Йорданова ${ }^{3}$ \\ ${ }^{1}$ Вирусологчческая лаборатория, УМБАЛ „Св. Марина“, Варна , Болгария \\ ${ }^{2}$ Кафедра микробиологии и вирусологии, Медицинский университет - Варна, Варна, Болгария \\ ${ }^{3}$ Кафедра акушерства и гинекологии, Медицинский университет - Варна, Варна, Болгария
}

Автор для корреспонденции: Живка Стойкова, Кафедра микробиологии и вирусологии, Медицинский университет - Варна, ул. „Марин Дринов“ № 55, 9002 Варна, Болгария; E-mail: jivita77@abv.bg.

Дата получения: 24 апреля $2019 \diamond$ Дата приемки: 2 августа $2019 \bullet$ Дата публикации: 30 июня 2020

Образец цитирования: Stoykova Zh, Ivanova L, Cvetkova S, Yordanova D. Congenital cytomegalovirus infection - lessons from a clinical case. Folia Med (Plovdiv) 2020;62(2):403-7. doi: 10.3897/folmed.62.e49840.

\section{Резюме}

Введение: Цитомегаловирус (CMV) - это вирус герпеса, распространяющийся по всему миру, который вызывает скрытую инфекцию после первичной инфекции. Это основная проблема у пациентов с ослабленным иммунитетом и в случаях первичной или реактивированной инфекции во время беременности. CMV является наиболее распространённой врождённой инфекцией и является основной инфекционной причиной нейросенсорной тугоухости и умственной отсталости головного мозга.

Цель: Привлечь внимание к противоречиям в наших знаниях о врождённой CMV-инфекции и применении наших знаний на практике.

Материалы и методы: ДНК CMV была выделена из образцов слюны и плазмы в соответствии с протоколом DNA-Sorb-A, Sacace, Biotechnology, Italy. Полимеразную цепную реакцию (ПЦР) проводили с использованием набора, основанного на принципе Taq-man: количественная RT-PCR для установления ДНК инфекции CMV (Sacace, Biotechnology, Italy). Линейный диапазон CMV Real-TM Quant PCR составляет 500-10000000 копий / мл, а заявленная чувствительность составляет 400 копий / мл.

Результаты: Ребёнок родился с клиническими проявлениями, включая развитие гепатоспленомегалии, хориоретинита, анемии, макроцефалии и сопутствующей дилатацией желудочков головного мозга. CMV-инфекция была подтверждена с помощью современных тестов ПЦР.

Выводы: В этом случае подчёркивается необходимость проведения специфических вирусологических / ПЦР-тестов для всех детей и при малейшем подозрении на врождённую инфекцию, особенно когда существует возможность для специфического лечения.

\section{Ключевые слова}

врождённая CMV, установление ДНК CMV инфекции, слюна, скрининг 